\title{
VALIDATION OF TOMATO POWDERY MILDEW FORECASTING MODEL USING METEOROLOGICAL DATA IN EGYPT
}

\author{
BAKEER A.R.T. ${ }^{*}$, ABDEL-LATEF M.A.E. ${ }^{2}$, AFIFI M.A. ${ }^{2}$ AND BARAKAT M.E. ${ }^{1}$ \\ ${ }^{1}$ Botany Department, Faculty of Agriculture, Fayoum University, 63414- Fayoum, Egypt. \\ 2Plant Pathology Institute, Agricultural Research Center, Egypt. \\ *Corresponding Author: Email- bakeer91@yahoo.com
}

Received: April 11, 2012; Accepted: October 15, 2013

\begin{abstract}
This study was initiated to validate a tomato powdery mildew, caused by Leveillula taurica (L'ev.) Arn., forecast model in Egypt. Environmentally acceptable control may be achieved using a weather based forecasting system due to the reduced use of agrochemicals and their residues in both environment and food. A computerized disease forecast model for tomato powdery mildew (Egy. Tom-PM) as named by the authors was validated during the 2006 and 2007 growing seasons. The micrometeorological parameters monitored hourly in tomato canopy were ambient air temperature, relative humidity, leaf wetness duration, wind speed and global radiation using a wireless real-time automatic Agro-weather station model (Adcon Telemetry model A733, add wave). Results indicated that Egy.Tom-PM forecast model accurately defined disease risk appearance and reduced number of sprays in both years compared with the routine application (10D) and (7D) sprays in 2006 and 2007 respectively. Basic roles of system analysis for model validation and evaluation are discussed.
\end{abstract}

Keywords- Leveillua taurica, Lycopersicon esculentum, Egy.Tom-PM forecast model

Citation: Bakeer A.R.T., et al (2013) Validation of Tomato Powdery Mildew Forecasting Model using Meteorological Data in Egypt. International Journal of Agriculture Sciences, ISSN: 0975-3710 \& E-ISSN: 0975-9107, Volume 5, Issue 2, pp.-372-378.

Copyright: Copyright@2013 Bakeer A.R.T., et al. This is an open-access article distributed under the terms of the Creative Commons Attribution License, which permits unrestricted use, distribution and reproduction in any medium, provided the original author and source are credited.

\section{Introduction}

Tomato (Lycopersicon esculentum Mill.) is very important vegetable crop in Egypt for both local consumption and exportation purposes. Powdery mildew, caused by Leveillula taurica (L'ev.) Arn., is the most important disease for tomato in both greenhouses and open fields. The anamorphic stage of Leveillula taurica found in tomato crop is known as Oidium taurica (L'ev.) Salmon [1]. Besides tomato, powdery mildew infects other vegetable crops such as pepper, eggplant, and cucumber [2]. The most common symptoms of tomato powdery mildew are yellow and necrotic spots on the upper leaf surface and powdery white spots on the lower side of the leaves [3]. Environmental conditions have a positive influence on tomato powdery mildew and greatly affect the disease development operation. Disease monitoring, early detection and prevention of tomato powdery mildew is critical. By the time tomato powdery mildew is detected in open fields many more leaves are already infected but do not show any disease symptoms or signs. In addition, The commonly observed symptoms of powdery mildew disease caused by L.taurica as light green to yellowish spots or blotches on the upper tomato leaf surface. While on the lower surface, fine whitish grey to purplish growth of the causal agent arises from the lower stomata. Later, infected areas of leaves dry up and turn into dark brown. Finally, the leaves may defoliate. Generally, the symptoms are considerably more visible on older leaves than on younger ones [4-7]. On the other hand, this disease does not infect the stem or fruit but causes general declines in growth, chief foliage damage, reduce the quality of fruits and finally, it sharply decreases tomato yield [8-
11]. Moreover, increasing resistance to fungicides by pathogens has greatly increased pre-and post harvest losses $[12,13]$. Tomato growers need to follow an intensive disease prevention plan because it is very important that powdery mildew never gets out of hand. Increasing concern for environment and food safety against fungicides application motivates farmers to optimize powdery mildew control by reducing chemical applications.

Monitoring of weather conditions within the plant canopy is possible by automated weather stations, real-time weather data can be transmitted from automated weather stations at remote sites to personal computers via telephone modems or by radio telemetry. Many attempts have been made to forecast tomato powdery mildew, or to provide systems that support the spray decision and replace the routine prophylactic spraying. All forecasts are based on determining the probability of weather that will favor infection and use of daily disease infection potential (DDIP) to produce risk warning and spray recommendations [14,15]. An electronic warning system for grape downy mildew, based on models for the infection of leaves of Vitis lambrusca, production of sporangia by Plasmopara viticola in lesions, and sporangial survival, was tested over 7 years in Ohio. Grapevines were sprayed with metalaxyl plus mancozeb (Ridomil MZ58) when the warning system indicated that environmental conditions were favorable for sporulation and subsequent infection. Effective control of downy mildew, therefore, can be achieved with the use of the warning system with fewer sprays than with a standard schedule [16]. 
The computerized model (Egy.Tom-PM) simulates the development of powdery mildew on the basis of short-term observation of microclimate factors. The input variables to the model are: temperature, Relative humidity, leaf wetness, wind speed and global radiation for the disease infection potential (DIP).

The objective of this research was to validate Egy.Tom-PM, the first Egyptian computerized forecasting model for better disease control with minimum fungicide use. It works by forecasting the most appropriate spray intervals to manage effective control of tomato powdery mildew, compared with routine fungicide application.

\section{Materials and Methods}

Disease Forecasting Model to Avoid Epidemics of Tomato's Powdery Mildew caused by Leveillula taurica

\section{Weather Monitoring}

Automated portable and solar powder in-crop weather stations with high technology named (Adcon Telemetry model A733add wave, [Fig-1] was used to monitor the microclimatological conditions. Every 15 minutes, digital data for temperature, relative humidity, wind speed, leaf wetness and global radiation within the canopy of tomato plants were transmitted via PC using radio waves up to $20 \mathrm{~km}$ in distance with no geographic obstacles. The meteorological data are transmitted automatically by radio from the weather station via data collection center (receiver) to receive and save the collected data for up to 50 days and advantage software which allows simple interpretation of the readings using a graph and detailed list of chosen items [Fig-2].

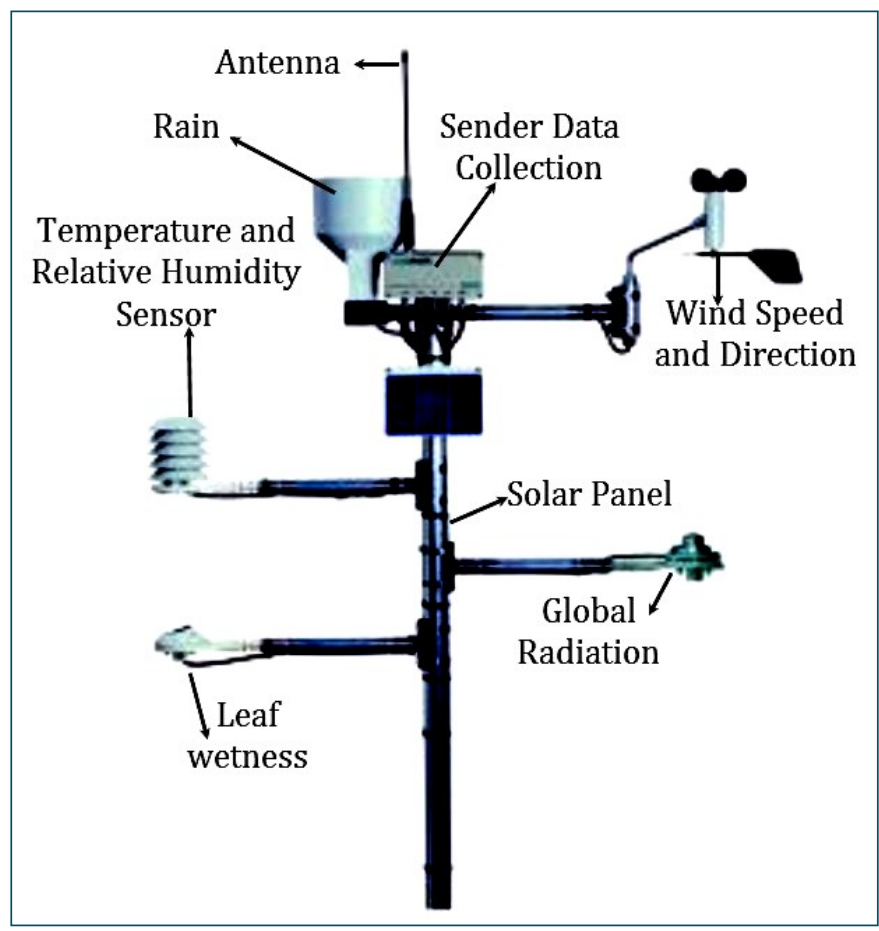

Fig. 1- The last generation of remote measuring agriculture weather stations for real time data around the world named Adcon Telemetry model A733.

\section{Tomato Powdery Mildew Forecast Model}

A computerized simulation software model named by the authors Egy.Tom-PM [Fig-3] was designed and tested several times under laboratory conditions before switching to a validation phase under field conditions at El-Khawagat village, Yousef El-Seddik County,
Fayoum governorate, Egypt during the 2006 and 2007 Nile tomato growing seasons. These experiments were used to figure out how well such a model forecast disease infection potential (DIP), which revised and refined based on these findings. Frequently, disease control (times of sprays) of grapes treated according to the model recommendations were compared to the disease managed by traditional routine spray schedules.

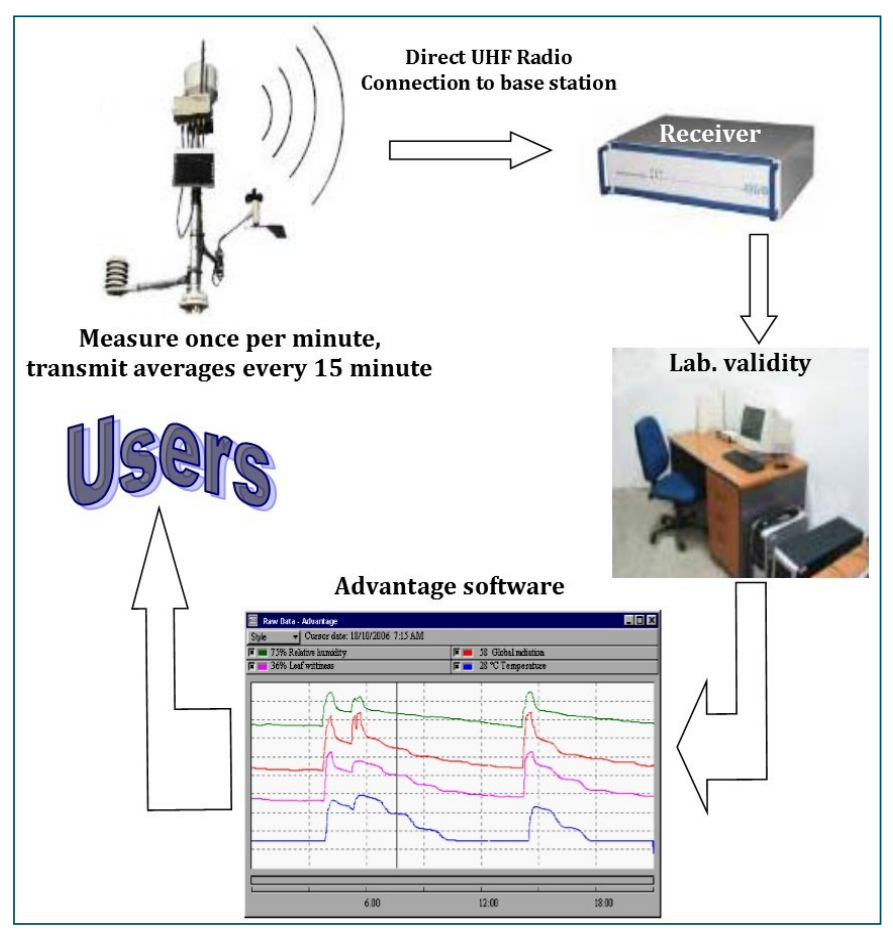

Fig. 2- Different stage of Data collection from weather station, throughout $\mathrm{PC}$ and advantage software to users.

\section{TOMATO POWDERY MILDEW FORECAST MODEL}
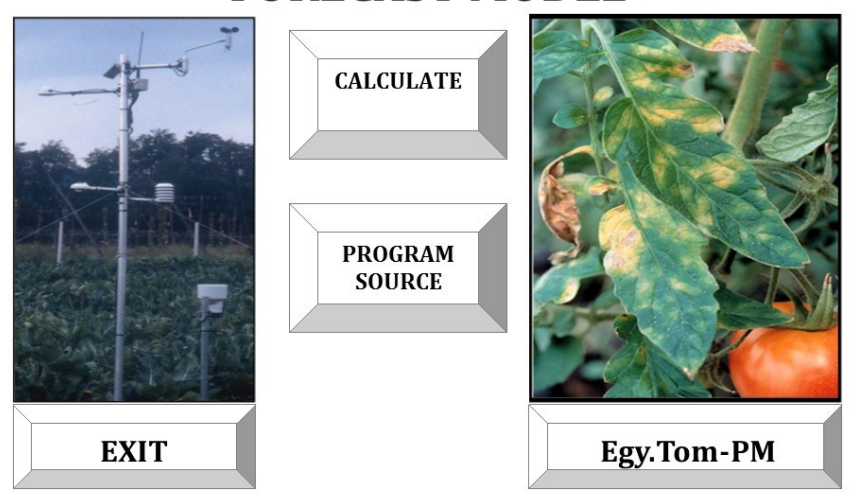

Fig. 3- Interface of Egy.Tom-PM program, the first record of disease forecast and early warning computerized model all over the Middle East area.

\section{The Computerized Model System Analysis}

Egy.Tom-PM model, presented as a flowchart [Fig-4] is a creation and designation of a computerized model, based on short-term observations (hourly weather data) analyzing the correlation between the input variables of microclimatological factors such as: temperature, relative humidity, wind speed, leaf wetness and global radiation and its effect on the disease daily infection potential 
(DDIP) of tomato powdery causal agent Leveillula taurica, to be calculated. Then, the model outputs a daily announcement as a warning message (spray or don't spray) to guide the fungicides application for perfect disease control in the appropriate time. The model evaluation follows the basic rules of system analysis to identify events ( $A$ and $B$ ). The model starts after the emergence phase is activated, and it tries to detect the event $A$, which is defined as: Event $A$ is triggered when the model detects at the least $X$ accumulated dynamic summation hours of $\mathrm{RH}>75$ and temperature between $Y$ and $Z$ according to the data tabulated in [Table-1]. Then the model looks for event $B$ which is continues hours of $\mathrm{RH}>85$ with temperature of the same value between $Y$ and $Z$. The $B$ event must happen within the $24 \mathrm{~h}$ of the $A$ event, but not later than $24 \mathrm{~h}$ after an A event. Moreover, using the model system analysis brings an extension to the model that applies the same rules not only to identify the first critical phase of the season, but also to issue warnings through the whole growing season (DIP).

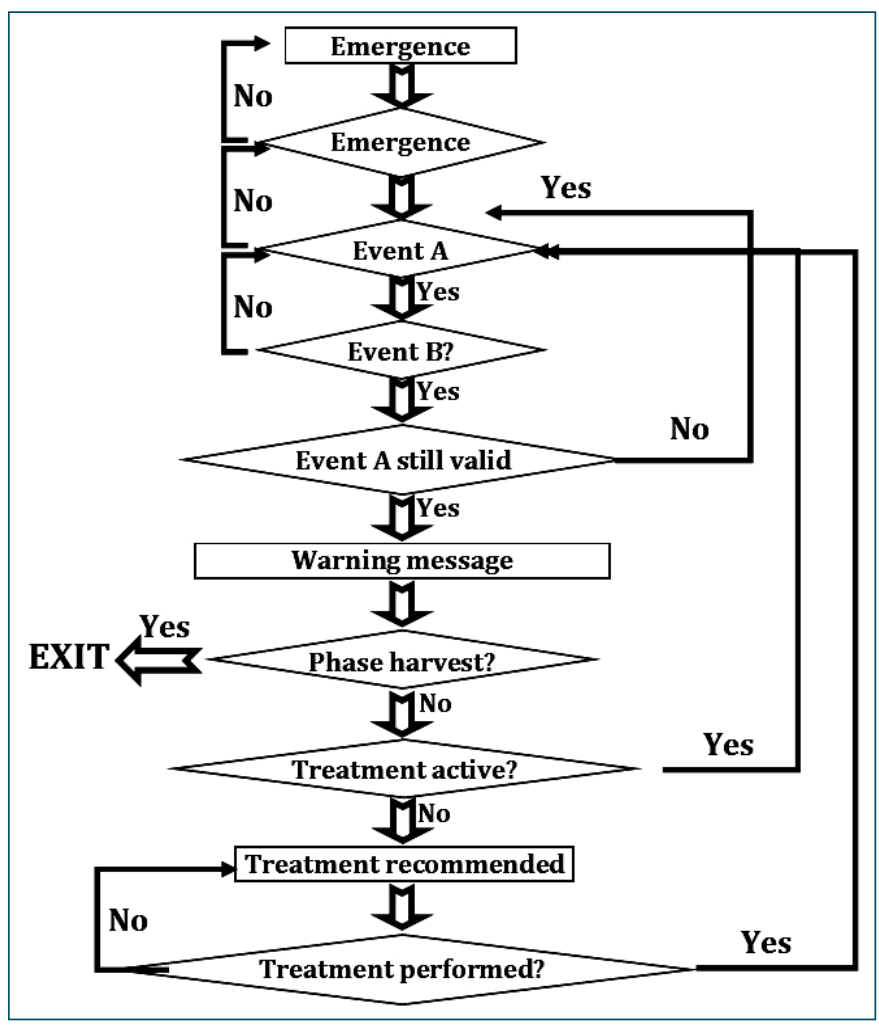

Fig. 4- Flowchart of system analysis for tomato powdery mildew computerized disease forecast model.

Table 1- Detection of $X$ accumulated dynamic summation hours of R.H. and Temperature (event $A$ )

$\mathrm{Y}=$ Temp from $\mathrm{Z}=$ Temp. to $\mathrm{X}=6 \mathrm{hrs}$. of $\mathrm{RH} \mathrm{X}=8 \mathrm{hrs}$. of RH $\mathrm{X}=10 \mathrm{hrs}$. of RH

\begin{tabular}{|c|c|c|c|c|}
\hline $10.0^{\circ} \mathrm{C}$ & $15.0^{\circ} \mathrm{C}$ & Event $\mathrm{A}$ detect & & \\
\hline $15.0^{\circ} \mathrm{C}$ & $20.0^{\circ} \mathrm{C}$ & & Event $\mathrm{A}$ detect & \\
\hline $20.0^{\circ} \mathrm{C}$ & $25.0^{\circ} \mathrm{C}$ & & & Event $\mathrm{A}$ detect \\
\hline
\end{tabular}

\section{Model Validation}

Field experiment was carried out at El-Khawagat village, Yousef ElSeddik County, Fayoum governorate, Egypt through both 2006 and 2007 tomato Nili growing seasons. The highly susceptible Hybrid 765 tomato seedlings were transplanted in the field in a randomized block design with three replicates per treatment. The following three treatments were tested: (i) a full-schedule fungicide program, in which plants were sprayed every 10 days; (ii) a full-schedule fungicide program, in which plants were sprayed every 7 days; (iii) spraying when nominal use of forecasting system indicated that a spray application was needed and at least 10 days had elapsed since the previous fungicide application. In addition, sulphur 250 $\mathrm{gm} / 100 \mathrm{~L}$ water and protectant fungicide (sumi-8) $35 \mathrm{~cm} 3 / 100 \mathrm{~L}$ water were used alternatively with some specific guidance (sprays should cover tomato plants, particularly on the under surface of the foliage and the lower plant canopy and should not be used during very warm, sunny weather to prevent phytotoxicity) were used for disease control as a recommended effective chemicals. Weekly tomato field inspection was initiated to ensure clear detection of the early signs of powdery mildew. Microclimate weather data were automatically collected $24 \mathrm{~h}$ a day by the advanced telemetry weather station (Adcon A 733), established within the tomato field canopy.

\section{Disease Assessment}

The percentage of disease severity was calculated using the equation suggested by Townsend \& Heuberger [17] as follows:

$$
\mathrm{P}=\frac{\left.\sum[\mathrm{a} \text { (rating no. }) \times \mathrm{b}(\text { no. leaves in rating category })\right]}{\mathrm{N}(\text { Total no. leaves }) \times \mathrm{K}(\text { highest rating value })} \times 100
$$

where :

$P=$ percentage of disease severity.

$a=$ number of leaves in each category.

$b=$ numerical value of each category.

$\mathrm{N}=$ total number of leaves in sample.

$\mathrm{K}=$ numerical value of the highest category.

A scale of scores was used in accordance with the leaf area affected, proposed by Ullasa, et al [18] of which:

1. Resistant (no symptoms).

2. Moderately resistant ( $10 \%$ of the leaf area affected).

3. Moderately susceptible (11-20\% of the leaf area affected).

4. Susceptible (21-50\% of the leaf area affected).

5. Highly susceptible (51\% or more of the leaf area affected).

\section{Results and Discussion}

The results of entire study indicated that Egy.Tom-PM program (Powdery mildew early warning computerized model) for tomato powdery mildew, which designed using the roles of system analysis, was successfully validated in Egypt under tomato field conditions allowing the best timing for fungicide application to reduce the number of fungicide applications for effectively control of powdery mildew compared with full schedule-fungicide program (routine application) with both (7D) and/or (10D) schedule. At the same time, the message of early warning model can forecast the probability of powdery mildew outbreak therefore avoid the exorbitant crop loss in such case with a consideration of powdery mildew epidemics had been recorded in deferent locations around the world. The results are expressed in an early warning message (spray and do not spray) in agreement with weekly field inspection. Data in [Table-2] show that at 2006 season, the warning message of Egy.Tom-PM program was to spray during September, October, November and December where they had one warning message for every one of them individually. In September, disease severity recorded $2.7 \%$ when temperature recorded $25.3,25.8$ and $26.6^{\circ} \mathrm{C}$ and R.H. $76.0,80.0$ and $83.0 \%$ in 23,24 and 25 September, respectively. 
Table 2- Implementation of Egy.Tom-PM program conjugate with daily average of microclimate factors during 2006 at Yousef ElSeddik county, Fayoum governorate

\begin{tabular}{|c|c|c|c|c|c|c|}
\hline Date & $\begin{array}{l}\text { Temp } \\
\left({ }^{\circ} \mathrm{C}\right)\end{array}$ & $\begin{array}{l}\text { R.H } \\
(\%)\end{array}$ & $\begin{array}{c}\text { Leaf wet. } \\
(\%)\end{array}$ & $\begin{array}{l}\text { Wind speed } \\
(\mathrm{Km} / \mathrm{h})\end{array}$ & $\begin{array}{l}\text { Global Radiation } \\
\text { (watt/m2) }\end{array}$ & $\begin{array}{l}\text { Disease } \\
\text { Severity }\end{array}$ \\
\hline \multicolumn{7}{|c|}{ September-2006 } \\
\hline 01-Sep & 32.3 & 47 & 24 & 3 & 51 & \\
\hline 02-Sep & 31.6 & 45 & 23 & 2 & 49 & \\
\hline 03-Sep & 30.4 & 43 & 21 & 4 & 46 & \\
\hline 04-Sep & 31.7 & 46 & 24 & 3 & 50 & \\
\hline 05-Sep & 32.5 & 50 & 27 & 1 & 53 & \\
\hline 06-Sep & 33.2 & 54 & 29 & 2 & 56 & \\
\hline 07-Sep & 31.6 & 49 & 26 & 4 & 54 & $0 \%$ \\
\hline 08-Sep & 30.2 & 47 & 25 & 3 & 51 & \\
\hline 09-Sep & 30.8 & 48 & 24 & 4 & 53 & \\
\hline 10-Sep & 29.5 & 45 & 22 & 5 & 50 & \\
\hline 11-Sep & 28.7 & 46 & 23 & 3 & 47 & \\
\hline 12-Sep & 29.3 & 50 & 25 & 2 & 49 & \\
\hline 13-Sep & 28.1 & 48 & 24 & 3 & 48 & \\
\hline 14-Sep & 27.6 & 45 & 22 & 4 & 46 & $0 \%$ \\
\hline 15-Sep & 26.8 & 47 & 21 & 3 & 44 & \\
\hline 16-Sep & 27.5 & 50 & 23 & 3 & 45 & \\
\hline 17-Sep & 28.9 & 52 & 25 & 4 & 48 & \\
\hline 18-Sep & 27.3 & 56 & 27 & 3 & 52 & \\
\hline 19-Sep & 25.4 & 60 & 24 & 2 & 54 & \\
\hline 20-Sep & 26.6 & 64 & 22 & 1 & 56 & \\
\hline 21-Sep & 27.9 & 68 & 23 & 2 & 55 & $1.8 \%$ \\
\hline 22-Sep & 26.5 & 72 & 25 & 2 & 54 & \\
\hline 23-Sep* & 25.3 & 76 & 24 & 1 & 56 & \\
\hline 24-Sep* & 25.8 & 80 & 22 & 1 & 55 & \\
\hline 25-Sep* & 26.6 & 83 & 25 & 1 & 58 & \\
\hline 26-Sep & 27.7 & 78 & 24 & 2 & 56 & \\
\hline 27-Sep & 28.8 & 74 & 22 & 1 & 54 & \\
\hline 28-Sep & 29.4 & 70 & 21 & 2 & 51 & $2.7 \%$ \\
\hline 29-Sep & 28.2 & 67 & 23 & 1 & 48 & \\
\hline 30-Sep & 28.6 & 65 & 25 & 1 & 50 & \\
\hline \multicolumn{7}{|c|}{ October-2006 } \\
\hline 01-Oct & 29.3 & 66 & 35 & 2 & 52 & \\
\hline $02-O c t$ & 28.2 & 63 & 33 & 3 & 54 & \\
\hline 03-Oct & 29.5 & 61 & 31 & 4 & 56 & \\
\hline 04-Oct & 28.6 & 62 & 32 & 2 & 53 & \\
\hline $05-O c t$ & 27.8 & 58 & 30 & 4 & 51 & \\
\hline $06-0 c t$ & 28.4 & 60 & 31 & 3 & 52 & \\
\hline 07-Oct & 29.5 & 64 & 33 & 1 & 54 & $0 \%$ \\
\hline 08-Oct & 30.1 & 67 & 34 & 2 & 56 & \\
\hline 09-Oct & 28.7 & 65 & 32 & 3 & 53 & \\
\hline 10-Oct & 27.3 & 68 & 34 & 1 & 50 & \\
\hline $11-$ Oct & 26.1 & 66 & 33 & 2 & 48 & \\
\hline 12-Oct & 27.4 & 70 & 35 & 1 & 49 & \\
\hline 13-Oct & 26.5 & 68 & 34 & 2 & 47 & \\
\hline 14-Oct & 27.1 & 71 & 33 & 3 & 48 & $0.9 \%$ \\
\hline 15-Oct & 26.6 & 74 & 35 & 2 & 46 & \\
\hline $16-O c t^{*}$ & 25.2 & 77 & 37 & 1 & 44 & \\
\hline 17-Oct* & 25.5 & 81 & 38 & 1 & 43 & \\
\hline 18-Oct* & 25.8 & 83 & 37 & 2 & 42 & \\
\hline $19-O c t$ & 26.4 & 84 & 36 & 3 & 44 & \\
\hline 20-Oct & 27.7 & 82 & 34 & 4 & 46 & \\
\hline 21-Oct & 28.5 & 84 & 33 & 3 & 48 & $2.5 \%$ \\
\hline 22-Oct & 29.3 & 81 & 31 & 4 & 49 & \\
\hline 23-Oct & 28.1 & 78 & 30 & 3 & 47 & \\
\hline 24-Oct & 27.6 & 73 & 27 & 4 & 45 & \\
\hline $25-O c t$ & 26.2 & 70 & 26 & 3 & 43 & \\
\hline 26-Oct & 27.5 & 74 & 29 & 2 & 44 & \\
\hline 27-Oct & 28.8 & 72 & 27 & 4 & 46 & $1.3 \%$ \\
\hline $28-O c t$ & 27.4 & 70 & 26 & 3 & 45 & \\
\hline $29-0 c t$ & 26.9 & 68 & 25 & 4 & 43 & \\
\hline $30-O c t$ & 27.2 & 72 & 27 & 3 & 44 & \\
\hline $31-O c t$ & 28.5 & 76 & 29 & 2 & 46 & \\
\hline
\end{tabular}

Table 2-Continue...

\begin{tabular}{|c|c|c|c|c|c|c|}
\hline Date & $\begin{array}{c}\text { Temp } \\
\left({ }^{\circ} \mathrm{C}\right)\end{array}$ & $\begin{array}{l}\text { R.H } \\
(\%)\end{array}$ & $\begin{array}{l}\text { Leaf wet. } \\
(\%)\end{array}$ & $\begin{array}{c}\text { Wind speed } \\
(\mathrm{Km} / \mathrm{h}) \\
\text { ovember-2006 }\end{array}$ & $\begin{array}{l}\text { Global Radiation } \\
\text { (watt/m2) }\end{array}$ & $\begin{array}{l}\text { Disease } \\
\text { Severity }\end{array}$ \\
\hline 01-Nov & 28.8 & 80 & 31 & 1 & 47 & \\
\hline 02-Nov & 28.3 & 78 & 29 & 2 & 46 & \\
\hline 03-Nov & 27.1 & 76 & 28 & 1 & 44 & \\
\hline 04-Nov & 26.7 & 74 & 26 & 2 & 43 & \\
\hline 05-Nov & 27.4 & 77 & 27 & 2 & 45 & \\
\hline 06-Nov & 28.6 & 80 & 29 & 4 & 47 & \\
\hline 07-Nov & 27.9 & 82 & 29 & 3 & 46 & $1.1 \%$ \\
\hline 08-Nov & 27.2 & 84 & 30 & 2 & 45 & \\
\hline 09-Nov & 26.4 & 81 & 28 & 2 & 43 & \\
\hline 10-Nov* & 25.1 & 83 & 29 & 1 & 41 & \\
\hline 11-Nov" & 25.7 & 86 & 31 & 2 & 41 & \\
\hline 12-Nov ${ }^{*}$ & 25.4 & 88 & 32 & 1 & 42 & \\
\hline 13-Nov & 24.3 & 84 & 30 & 3 & 40 & \\
\hline 14-Nov & 23.6 & 81 & 28 & 2 & 38 & $2.9 \%$ \\
\hline 15-Nov & 22.7 & 77 & 29 & 3 & 39 & \\
\hline 16-Nov & 23.5 & 74 & 26 & 4 & 37 & \\
\hline 17-Nov & 22.8 & 71 & 23 & 4 & 36 & \\
\hline 18-Nov & 23.9 & 73 & 24 & 3 & 34 & \\
\hline 19-Nov & 23.1 & 71 & 25 & 3 & 36 & \\
\hline 20-Nov & 24.3 & 72 & 26 & 4 & 37 & \\
\hline 21-Nov & 25.6 & 75 & 24 & 3 & 39 & $1.6 \%$ \\
\hline 22-Nov & 24.7 & 72 & 21 & 4 & 38 & \\
\hline 23-Nov & 24.2 & 70 & 20 & 3 & 37 & \\
\hline 24-Nov & 25 & 68 & 18 & 4 & 39 & \\
\hline 25-Nov & 24.1 & 66 & 16 & 3 & 38 & \\
\hline 26-Nov & 24.7 & 64 & 15 & 4 & 40 & \\
\hline 27-Nov & 23.5 & 61 & 13 & 3 & 39 & \\
\hline 28-Nov & 24.8 & 63 & 14 & 3 & 41 & $0 \%$ \\
\hline 29-Nov & 24.3 & 65 & 16 & 2 & 40 & \\
\hline 30-Nov & 23.6 & 62 & 15 & 3 & 38 & \\
\hline & & & & ecember-2006 & & \\
\hline 01-Dec & 26.5 & 76 & 29 & 1 & 44 & \\
\hline 02-Dec & 25.1 & 74 & 27 & 2 & 42 & \\
\hline 03-Dec & 24.8 & 73 & 26 & 1 & 41 & \\
\hline 04-Dec & 24.3 & 70 & 24 & 2 & 40 & \\
\hline 05-Dec & 25.6 & 74 & 25 & 1 & 42 & $0.7 \%$ \\
\hline $06-\mathrm{Dec}^{*}$ & 26.4 & 77 & 27 & 3 & 43 & \\
\hline 07-Dec ${ }^{*}$ & 25.2 & 78 & 26 & 2 & 44 & \\
\hline 08-Dec ${ }^{*}$ & 24.9 & 80 & 28 & 1 & 42 & \\
\hline 09-Dec & 24.5 & 77 & 26 & 3 & 41 & \\
\hline 10-Dec & 23.4 & 80 & 27 & 2 & 38 & \\
\hline 11-Dec & 23.1 & 83 & 29 & 2 & 36 & \\
\hline 12-Dec & 22.6 & 85 & 31 & 3 & 37 & $22 \%$ \\
\hline 13-Dec & 22 & 82 & 29 & 2 & 36 & \\
\hline 14-Dec & 21.4 & 78 & 27 & 3 & 35 & \\
\hline 15-Dec & 20.5 & 74 & 26 & 3 & 36 & \\
\hline 16-Dec & 21.7 & 71 & 25 & 2 & 37 & \\
\hline 17-Dec & 20.3 & 68 & 23 & 1 & 33 & \\
\hline 18-Dec & 21.5 & 70 & 22 & 1 & 32 & \\
\hline 19-Dec & 20.6 & 67 & 24 & 2 & 34 & $1 \%$ \\
\hline 20-Dec & 21.9 & 69 & 25 & 3 & 35 & \\
\hline 21-Dec & 22.4 & 72 & 22 & 1 & 37 & \\
\hline 22-Dec & 21.8 & 69 & 20 & 2 & 35 & \\
\hline 23-Dec & 22.1 & 66 & 18 & 1 & 36 & \\
\hline 24-Dec & 23.3 & 64 & 16 & 1 & 38 & \\
\hline 25-Dec & 22.5 & 62 & 15 & 2 & 36 & \\
\hline 26-Dec & 22.8 & 61 & 13 & 1 & 37 & \\
\hline 27-Dec & 21.4 & 58 & 11 & 1 & 38 & $0 \%$ \\
\hline 28-Dec & 22.6 & 60 & 12 & 2 & 39 & \\
\hline 29-Dec & 22 & 62 & 14 & 3 & 37 & \\
\hline 30-Dec & 21.3 & 59 & 13 & 2 & 35 & \\
\hline 31-Dec & 20.5 & 56 & 15 & 3 & 33 & \\
\hline "Disease & $\begin{array}{l}\text { severity c } \\
\text { SPRAY" }\end{array}$ & & powde & Idew thro & daily alert f & \\
\hline
\end{tabular}


Moreover, during October disease severity recorded $2.5 \%$ when temperature recorded $25.2,25.5$ and $25.8^{\circ} \mathrm{C}$ and R.H. $77.0,81.0$ and $83.0 \%$ in 16, 17 and 18 October, respectively. Moreover, disease severity recorded $2.9 \%$, during November, when temperatures were $25.1,25.7$ and $25.4^{\circ} \mathrm{C}$ and R.H. were $83.0,86.0$ and $88.0 \%$ in 10,11 and 12 November, respectively. During December, disease severity recorded $2.2 \%$ when temperature recorded $26.4,25.2$ and $24.9^{\circ} \mathrm{C}$ and R.H. $77.0,78.0$ and $80.0 \%$ in 6,7 and 8 December, respectively.

On the other hand, data in [Table-3] show that at the 2007 season, the warning message of Egy.Tom-PM program was to spray during September once when temperature recorded $25.4,25.9$ and $25.1^{\circ} \mathrm{C}$ where R.H. were recorded $81.0,84$ and $87.0 \%$ at 14,15 and 16 September, respectively, and disease severity was $3.5 \%$. During October, warning messages were twice. The disease severity was recorded twice, the first $3.8 \%$ when temperatures recorded 25.6 , 25.9 and $26.4^{\circ} \mathrm{C}$ and R.H. were 82,85 and $88 \%$ at 19,20 and 21 October, respectively. The Second disease severity was $2.4 \%$ when temperatures recorded $25.4,25.8$ and $26.2^{\circ} \mathrm{C}$, and R.H was 90,93 and $96 \%$, throughout days 28,29 and 30 days of October, respectively. During November disease severity, was $3.4 \%$ when temperatures were $25.4,25.7$ and $25.1^{\circ} \mathrm{C}$ and R.H. recorded 93,94 and $92 \%$ during 2, 3 and 4 November, respectively. Moreover, during December, disease severity was only recorded once, being $3.2 \%$ when temperatures were $24.4,25.1$ and $24.8^{\circ} \mathrm{C}$ and R.H. 91 , 89 and $92 \%$ during 1, 2 and 3 December, respectively.

As a matter of fact, in this study the application of tomato powdery mildew disease forecast and early warning model, using a designed computerized model adopted with role of system analysis has been done for the first time not only in Egypt but also all over Arabian and African countries. According to the literature, it is also the first description of powdery mildew all over the Middle East area. Results in this point showed that using advanced last generation of agrometerological remote weather station to collect the daily microclimate elements (the disease forecast and early warning input data) was agreement with Hstgaard [19] who reported that a fully equipped weather station with wireless data transmission, the Hardi MetpoleReg., and its presentation software developed for use by farmers. The Hardi MetpoleReg, was equipped with sensors for collecting wind velocity, surface wetness, global radiation, air temperature, relative humidity and rainfall data at various heights above the ground. Data were transmitted by radio waves to a receiver at the farm and presented using the computer software. All data are transferable to ASCII-format files for use in computerized monitoring and forecasting systems. Powdery mildew of tomato caused by $L$. taurica in considered one of the most limiting diseases for tomato production and could be controlled effectively in Egypt for the first time with fewer fungicide applications than a slandered calendar - based schedule with system of disease forecast using computerized model Egy - Tom - PM. This model resulted in a noticeable reduction in fungicide application and consequently reduced the number of sprays. During the 2006 season there were four warning messages in September, October, November and December individually. On the other hand, in 2006 season there were one, two, one and one warning messages in September, October, November and December, respectively. The previous results may be due to the favorable weather conditions, especially under optimum temperature (20-25) and R.H. ranging between $75-90 \%$ in which tomato powdery mildew (L. taurica) needs to development and progress.
Table 3- Implementation of Egy.Tom-PM program conjugate with daily average of microclimate factors during 2007 at Yousef El-

Seddik county, Fayoum governorate

\begin{tabular}{|c|c|c|c|c|c|c|}
\hline Date & $\begin{array}{l}\text { Temp } \\
\left({ }^{\circ} \mathrm{C}\right)\end{array}$ & $\begin{array}{l}\text { R.H } \\
(\%)\end{array}$ & $\begin{array}{l}\text { Leaf wet. } \\
\begin{array}{c}\text { (\%) } \\
\text { Sep }\end{array}\end{array}$ & $\begin{array}{l}\text { Wind speed } \\
(\mathrm{Km} / \mathrm{h}) \\
\text { tember-2007 }\end{array}$ & $\begin{array}{l}\text { Global Radiation } \\
\text { (watt/m2) }\end{array}$ & $\begin{array}{l}\text { Disease } \\
\text { Severity }\end{array}$ \\
\hline 01-Sep & 30.6 & 65 & 36 & 3 & 44 & \\
\hline 02-Sep & 29.5 & 67 & 33 & 2 & 42 & \\
\hline 03-Sep & 28.7 & 70 & 31 & 1 & 40 & \\
\hline 04-Sep & 29.1 & 73 & 34 & 2 & 41 & \\
\hline 05-Sep & 30.4 & 77 & 37 & 1 & 43 & \\
\hline 06-Sep & 31.3 & 79 & 40 & 2 & 46 & \\
\hline 07-Sep & 29.8 & 81 & 37 & 1 & 44 & 0 \\
\hline 08-Sep & 28.5 & 78 & 35 & 3 & 42 & \\
\hline 09-Sep & 28.9 & 80 & 36 & 2 & 43 & \\
\hline 10-Sep & 27.6 & 77 & 34 & 3 & 41 & \\
\hline 11-Sep & 26.3 & 75 & 32 & 2 & 38 & \\
\hline 12-Sep & 26.7 & 77 & 33 & 3 & 39 & \\
\hline 13-Sep & 26.1 & 78 & 31 & 2 & 37 & \\
\hline 14-Sep* & 25.4 & 81 & 34 & 1 & 35 & 1.2 \\
\hline $15-\mathrm{Sep}^{*}$ & 25.9 & 84 & 36 & 2 & 36 & \\
\hline 16-Sep* & 25.1 & 87 & 38 & 1 & 38 & \\
\hline 17-Sep & 27 & 85 & 40 & 3 & 41 & \\
\hline 18-Sep & 28.3 & 87 & 38 & 2 & 43 & \\
\hline 19-Sep & 29.6 & 84 & 36 & 3 & 46 & \\
\hline 20-Sep & 28.8 & 79 & 34 & 4 & 44 & \\
\hline 21-Sep & 27.5 & 76 & 32 & 3 & 42 & 3.5 \\
\hline 22-Sep & 28.4 & 77 & 33 & 4 & 45 & \\
\hline 23-Sep & 29.1 & 79 & 35 & 4 & 47 & \\
\hline 24-Sep & 30.7 & 82 & 38 & 3 & 50 & \\
\hline 25-Sep & 30.2 & 80 & 36 & 2 & 48 & \\
\hline 26-Sep & 29 & 75 & 33 & 3 & 46 & \\
\hline 27-Sep & 28.4 & 70 & 30 & 4 & 44 & \\
\hline 28-Sep & 27 & 67 & 28 & 2 & 41 & 1.8 \\
\hline 29-Sep & 26.2 & 63 & 26 & 3 & 39 & \\
\hline 30-Sep & 27.5 & 66 & 28 & 2 & 37 & \\
\hline \multicolumn{7}{|c|}{ October-2007 } \\
\hline 01-Oct & 26.3 & 63 & 25 & 2 & 35 & \\
\hline 02-Oct & 27.5 & 65 & 26 & 3 & 37 & \\
\hline 03-Oct & 28.8 & 68 & 28 & 1 & 39 & \\
\hline 04-Oct & 27.4 & 66 & 27 & 2 & 38 & \\
\hline 05-Oct & 28.6 & 69 & 29 & 1 & 40 & \\
\hline 06-Oct & 29.1 & 71 & 30 & 3 & 43 & \\
\hline 07-Oct & 28.5 & 74 & 32 & 1 & 41 & 0 \\
\hline 08-Oct & 28 & 72 & 31 & 2 & 40 & \\
\hline 09-Oct & 27.3 & 69 & 28 & 3 & 39 & \\
\hline 10-Oct & 26.7 & 73 & 31 & 1 & 37 & \\
\hline 11-Oct & 25.5 & 70 & 29 & 2 & 35 & \\
\hline 12-Oct & 26.2 & 73 & 32 & 1 & 36 & \\
\hline 13-Oct & 25.4 & 69.1 & 28 & 3 & 34 & \\
\hline 14-Oct & 26 & 73 & 30 & 2 & 35 & 1.5 \\
\hline 15-Oct & 27.3 & 78 & 33 & 1 & 35 & \\
\hline 16-Oct & 26.1 & 75 & 31 & 2 & 33 & \\
\hline 17-Oct & 26.6 & 77 & 32 & 2 & 34 & \\
\hline 18-Oct & 25.2 & 80 & 34 & 1 & 34 & \\
\hline $19-O c t^{*}$ & 25.6 & 82 & 36 & 1 & 35 & \\
\hline $20-0 \mathrm{ct}^{\star}$ & 25.9 & 85 & 38 & 1 & 36 & \\
\hline $21-O c t^{*}$ & 26.4 & 88 & 37 & 2 & 37 & \\
\hline 22-Oct & 24.8 & 84 & 34 & 3 & 35 & 3.8 \\
\hline 23-Oct & 25.5 & 87 & 36 & 2 & 36 & \\
\hline 24-Oct & 26.1 & 89 & 37 & 2 & 37 & \\
\hline $25-O c t$ & 27.6 & 86 & 35 & 3 & 40 & \\
\hline 26-Oct & 26.3 & 83 & 33 & 3 & 42 & \\
\hline 27-Oct & 26.9 & 87 & 35 & 2 & 40 & \\
\hline $28-O c^{*}$ & 25.4 & 90 & 37 & 1 & 38 & \\
\hline $29-0 \mathrm{ct}^{*}$ & 25.8 & 93 & 38 & 2 & 36 & \\
\hline 30-Oct* & 26.2 & 96 & 40 & 2 & 38 & \\
\hline $31-0 \mathrm{ct}$ & 27.5 & 94 & 38 & 3 & 40 & $2.4 \%$ \\
\hline
\end{tabular}


Table 3-Continue...

\begin{tabular}{|c|c|c|c|c|c|c|}
\hline Date & $\begin{array}{l}\text { Temp } \\
\left({ }^{\circ} \mathrm{C}\right)\end{array}$ & $\begin{array}{l}\text { R.H } \\
\text { (\%) }\end{array}$ & $\begin{array}{l}\text { Leaf wet. } \\
\begin{array}{l}(\%) \\
\text { No }\end{array}\end{array}$ & $\begin{array}{l}\text { Wind speed } \\
(\mathrm{Km} / \mathrm{h}) \\
\text { vember-2007 }\end{array}$ & $\begin{array}{l}\text { Global Radiation } \\
\text { (watt/m2) }\end{array}$ & $\begin{array}{l}\text { Disease } \\
\text { Severity }\end{array}$ \\
\hline 01-Nov & 26.3 & 95 & 39 & 1 & 38 & \\
\hline 02-Nov & $25.4^{*}$ & 93 & 37 & 2 & 36 & \\
\hline 03-Nov & $25.7^{*}$ & 94 & 38 & 2 & 37 & \\
\hline 04-Nov & $25.1^{*}$ & 92 & 36 & 1 & 35 & \\
\hline 05-Nov & 24.5 & 88 & 35 & 3 & 37 & \\
\hline 06-Nov & 23.3 & 86 & 34 & 2 & 36 & \\
\hline 07-Nov & 22.6 & 82 & 31 & 3 & 34 & $3.4 \%$ \\
\hline 08-Nov & 23.5 & 84 & 30 & 1 & 33 & \\
\hline 09-Nov & 22.2 & 80 & 29 & 3 & 34 & \\
\hline 10-Nov & 21 & 77 & 31 & 2 & 36 & \\
\hline 11-Nov & 22.4 & 75 & 30 & 3 & 35 & \\
\hline 12-Nov & 23.7 & 77 & 29 & 2 & 34 & \\
\hline 13-Nov & 24.8 & 76 & 27 & 3 & 32 & \\
\hline 14-Nov & 23.1 & 74 & 28 & 2 & 33 & $0 \%$ \\
\hline 15-Nov & 23.5 & 72 & 26 & 3 & 31 & \\
\hline 16-Nov & 22.1 & 69 & 24 & 2 & 30 & \\
\hline 17-Nov & 21.7 & 66 & 22 & 3 & 28 & \\
\hline 18-Nov & 22.6 & 69 & 23 & 2 & 29 & \\
\hline 19-Nov & 23.2 & 72 & 24 & 1 & 30 & \\
\hline 20-Nov & 23.5 & 73 & 25 & 2 & 30 & \\
\hline 21-Nov & 22.7 & 70 & 26 & 3 & 32 & $0 \%$ \\
\hline 22-Nov & 21.4 & 68 & 28 & 2 & 33 & \\
\hline 23-Nov & 20.8 & 66 & 29 & 1 & 32 & \\
\hline 24-Nov & 21.1 & 67 & 30 & 2 & 34 & \\
\hline 25-Nov & 22.2 & 69 & 32 & 3 & 33 & \\
\hline 26-Nov & 21.7 & 67 & 33 & 2 & 33 & \\
\hline 27-Nov & 20.4 & 64 & 34 & 2 & 31 & \\
\hline 28-Nov & 21.6 & 65 & 32 & 3 & 29 & $0 \%$ \\
\hline 29-Nov & 22.2 & 67 & 30 & 2 & 28 & \\
\hline 30-Nov & 23 & 70 & 31 & 1 & 30 & \\
\hline \multicolumn{7}{|c|}{ December-2007 } \\
\hline 01-Dec & $24.4^{*}$ & 91 & 36 & 2 & 35 & \\
\hline 02-Dec & $25.1^{*}$ & 89 & 34 & 2 & 32 & \\
\hline 03-Dec & $24.8^{*}$ & 92 & 35 & 1 & 34 & \\
\hline 04-Dec & 23.5 & 88 & 33 & 2 & 33 & \\
\hline 05-Dec & 22 & 85 & 31 & 3 & 34 & \\
\hline 06-Dec & 21.4 & 82 & 30 & 3 & 32 & \\
\hline 07-Dec & 20.2 & 78 & 28 & 4 & 31 & $3.2 \%$ \\
\hline 08-Dec & 20.8 & 81 & 27 & 2 & 30 & \\
\hline 09-Dec & 21.3 & 77 & 26 & 2 & 31 & \\
\hline 10-Dec & 19.7 & 73 & 28 & 3 & 33 & \\
\hline 11-Dec & 20.5 & 71 & 27 & 3 & 31 & \\
\hline 12-Dec & 21.1 & 74 & 26 & 1 & 30 & \\
\hline 13-Dec & 22.4 & 72 & 24 & 2 & 30 & \\
\hline 14-Dec & 21.6 & 70 & 25 & 3 & 31 & $0 \%$ \\
\hline 15-Dec & 20.9 & 68 & 23 & 3 & 29 & \\
\hline 16-Dec & 20.2 & 65 & 21 & 4 & 27 & \\
\hline 17-Dec & 19.5 & 62 & 18 & 4 & 26 & \\
\hline 18-Dec & 20.1 & 66 & 20 & 3 & 27 & \\
\hline 19-Dec & 21 & 69 & 22 & 2 & 28 & \\
\hline 20-Dec & 21.6 & 71 & 21 & 1 & 27 & \\
\hline 21-Dec & 20.4 & 68 & 23 & 2 & 29 & $0 \%$ \\
\hline 22-Dec & 19.7 & 65 & 25 & 3 & 30 & \\
\hline 23-Dec & 18.3 & 62 & 27 & 4 & 29 & \\
\hline 24-Dec & 18.9 & 64 & 28 & 3 & 31 & \\
\hline 25-Dec & 20.3 & 67 & 29 & 2 & 30 & \\
\hline 26-Dec & 19.2 & 64 & 30 & 3 & 31 & \\
\hline 27-Dec & 18.5 & 60 & 31 & 4 & 28 & \\
\hline 28-Dec & 19.6 & 61 & 30 & 3 & 26 & $0 \%$ \\
\hline 29-Dec & 20.4 & 64 & 27 & 2 & 25 & \\
\hline 30-Dec & 21.1 & 67 & 29 & 1 & 27 & \\
\hline 31-Dec & 20 & 65 & 26 & 2 & 26 & \\
\hline
\end{tabular}

The results are in harmony with these obtained by Reuveni, et al [20], Fiume [21] and Guzman-Plazola, et al. Egy-Tom-PM development of certain disease into a computer-based model and then forecast the disease under different environmental conditions has been discussed in detail. The model was very accurate in simulating successful daily infection potential (DIP), because all the observed disease appearance in the tomato open field were correctly simulated by the model. In addition to the work presented here, Davis \& Marois [14], Guzman-Plazola [15] and Seem [23] found that effective control of tomato powdery mildew could be achieved in California when protectant fungicides were applied according to a spray forecast model. Moreover, disease symptoms were never observed when the model did not signal a successful infection, even though the starting date for fungicide applications was accurately determined.

\section{Conclusion}

The results obtained have emphasised how for tomato protection applications, the use of disease forecasting program for tomato powdery mildew was applied after program validity test during two successive seasons 2006 and 2007 at El-Khawagat village, Yousef El-Seddik County, Fayoum governorate, Egypt. Powdery mildew forecast program reduced the number of application times of fungicides compared with control. Simulation models based on agrometeorological variables and the energy balance could therefore be an important tool for operational applications. Their integration with the development of disease simulation models is of great importance regarding the application time of fungicide sprays and reduce the number of total applications numbers [24] while maintaining a high quality of production with a low impact on the environment. As there was a good agreement between model outputs and actual disease severity, the model can be considered as a satisfactory simulator of the effect of environmental conditions on the progress of powdery mildew epidemics. These approaches have proved useful in describing control effectiveness and, in some cases, optimizing or changing control practices [25,26]

Conflicts of Interest : None declared.

\section{References}

[1] Whipps J.M., Budge S.P., Fenlon J.S. (1998) Plant Pathol., 47 (1), 36-48.

[2] Palti J. (1988) Botanical Review., 54, 423-535.

[3] Holliday P. (1980) Fungus Diseases of Tropical Crops, Cambridge University Press, New York, 607.

[4] Correll J.C., Gordon J.R., Elliott Y.J. (1988) California Agric., 42 (2), 8-10.

[5] McGrath M.T., Shishkoff N., Bornt C., Moyer D.D. (2001) Plant Dis., 85(10), 1122.

[6] Haroun S.H. (2002) Studies on Powdery Mildew Disease on Tomatoes in Egypt, Ph.D. Thesis, Fac. Agric. Moshtohor, Zagazig Univ., 166.

[7] Reis A., Lopes C.A., Paz-Lima M.L., Boiteux L.S. (2004) Fitopatologia Brasileira, Fortaleza, 29(3), 339.

[8] Natour R.M., El-Behadi A.H., Majeed M.G. (1971) Plant Dis., 55 (2), 192.

[9] Jones W.B., Thomson S.V. (1987) Plant. Dis., 71(3), 266-268.

[10]Schickedanz F. (1989) Pflanzenschutzdienstes, 41(12), $207-$ 208. 
[11]Farag F.M. (2003) Studies on powdery mildew disease affecting solanaceous plant, M.Sc. Thesis, Fac. of Agric. Cairo Univ., 105.

[12]Braun U. (1987) Beih Nova Hedwigia., 89, 1-700.

[13]Correll J.C., Gordon T.R., Elliott V.J. (1987) Plant Dis., 71(3), 248-251.

[14]Davis R.M., Marois J.J. (1995) Development of a spray forecast model for powdery mildew of tomato, California Tomato Research Institute Final Report, 52-59.

[15]Guzman-Plazola R.A. (1997) Development of spray forecast model for tomato powdery mildew (Leveillula taurica (Lev) Arn.) Ph.D. Thesis, University of California.

[16]Madden L.V., Ellis M.A., Lalancette N., Hughes G., Wilson L.L. (2000) Plant. Dis., 84, 549-554.

[17]Townsend G.R. and Heuberger J.W. (1943) Plant Dis. Rep., 27, 340-343.

[18]Ullasa B.A., Rawal R.D., Sohi H.S., Singh D.P., Joshi M.C. (1981) Plant Dis., 65, 600-601.

[19]Hstgaard M.B. (1995) 36th Swedish Crop Protection Conference: Agriculture Pests Diseases/Weeds, Uppsala, Sweden, 249-259.

[20]Reuveni R., Perl M., Rotem J. (1974) Phytopathologische Zeitscrift, 80(1), 79-84.

[21]Fiume F. (1997) 49th International Symposium on Crop Prot., Gent, Belgium.

[22]Guzman-Plazola R.A., Davis R.M., Marois J.J. (2003) Crop Protection, 22(10), 1157-1168.

[23]Seem R. (2001) Plant Pathology, Kyongiu, Republic of Korea.

[24]Magarey R.D., Russo J.M., Seem R.C., Gadoury D.M. (2005) Agricultural and Forest Meteorology, 128(1), 111-122.

[25]Rossi V. and Giosue S. (2003) Bull. OEPP., 33(3), 389-396.

[26]Jeger M.J. (2004) Ann. Rev. Phytopathol., 42, 61-82. 